\title{
The Correlation Analysis of Education Level and Regional Economic Growth Quality in Guangdong Province
}

\author{
Yun Sun ${ }^{1}$, Yu Qin ${ }^{2}$, Yuanke $\mathrm{Hu}^{2}$, Shaosong Wang ${ }^{2, *}$ and Xiaosong $\mathrm{Bi}^{1}$ \\ ${ }^{1}$ International Business and Management Research Center, Beijing Normal University at Zhuhai, Guangdong 510085 , \\ China \\ ${ }^{2}$ School of Business, Macau University of Science and Technology, Macau SAR, China \\ *Corresponding author. Email: sswang@must.edu.mo
}

\begin{abstract}
Under the background of China's slowing economic development trend, Guangdong Provincial Government took the lead in putting forward the innovation-driven development strategy. The level of educational efficiency is closely related to the quality of regional economic growth. This paper examed the relationship between educational efficiency level and economic growth quality in Guangdong Province. Though the Entropy and Grey correlation analysis of between educational efficiency level index and economic growth quality index from 2004 to 2019, the conclusion is drawn that a significantly impact of education level on economic growth in Guangdong. The results suggested the importance of education, particularly for the impact on economic growth.

Keywords: Education level; The quality of economy growth; Data envelopment analysis; Grey correlation
\end{abstract}

\section{INTRODUCTION}

Under the background of China's slowing economic development trend, Guangdong Provincial Government took the lead in putting forward the innovation-driven development strategy. Improving and optimizing the inputoutput efficiency of the education system is an indispensable strategic policy for improving the overall level of regional education and cultivating high-quality talents to drive the high-quality development of regional economy. In order to find the relationship between educational level and economic growth, this paper examed the regional education level in Guangdong province, and finds out the problems of redundant input and insufficient output in educational input and output, so as to improve the efficiency of educational resource allocation and coordinate the common development of economy.

\section{LITERATURE REVIEW}

The selection of indicators is based on China's national conditions, combined with the principle of comprehensiveness, simplicity and feasibility. For education indicators, (OECD) Based on the development of The Times and the status quo of education development, four complete educational index systems, including output index, input index, opportunity index and process index, have been gradually formed. Xue-min zhang, Xin chen (2019) since the founding of the Chinese education standards, evaluation methods and the trend of evolution characteristics, clarify the connotation of the evaluation standard, basic methods and indicators. To measure the index of economic quality, the academic circle takes the broad view as a more comprehensive interpretation.[1] Bianhua Li (2004) believes that the index system to measure the quality of economic development should include eight aspects: economic stability, scientific and technological progress, environmental protection, competitiveness, people's livelihood, economic stability, economic efficiency and economic structure.[2] Xiaojing Chao (2010) believes that four dimensions are adopted to measure the quality of economic growth: economic growth structure, economic growth stability, welfare change and achievement distribution, resource utilization and ecological environment cost. Therefore, this paper selects four levels of economic quality to measure.[3] The index evaluation table is shown in Table 1 and Table 2

\section{RESEARCH METHODS}

\subsection{Principal component analysis and applicability}

In the process of multi-index evaluation and decision making, there is often a large amount of index information, and there is correlation among indexes, which affects the accuracy and effectiveness of index evaluation. Principal component analysis uses mathematical transformation to 
form a new linear combination of variables and principal components, and selects the principal components with large variation information to analyze the educational level. The applicability of the principal components was tested by the sample adequacy and sphericity of KMO.

\subsection{DEA data envelopment analysis}

Shanmai Wang(1995) believes that educational efficiency, as a kind of production or economic activity, is transplanted from the perspective of economics, and its efficiency covers educational investment, utilization of educational resources, internal benefits of educational investment and other aspects.[4] Xing Chen and Xuemin Zhang(2019) further put forward the data envelopment analysis (DEA) as the standard research method for studying educational efficiency.[5] Data Envelopment Analysis (DEA) model has become the most commonly used model to evaluate efficiency. It is a method based on relative efficiency theory and using mathematical programming theory to evaluate the efficiency of decision making units with various inputs and outputs. This paper also adopts this method, choosing input and output as the guide to carry out the analysis.

$$
\left\{\begin{array}{c}
\min \left[\theta-\varepsilon\left(\sum_{r=1}^{t} s_{r}^{+}+\sum_{i=1}^{m} s_{i}^{-}\right)\right] \\
\sum_{j=1}^{n} \lambda_{j} x_{i j}+s_{i}^{-}=\theta x_{i j} \\
\sum_{j=1}^{n} \lambda_{j} y_{r j}-s_{r}^{+}=y_{r j} \quad(j=1,2, \ldots, n) \\
\lambda_{j} \geq 0 \\
s_{i}^{-} \geq 0 \\
s_{r}^{+} \geq 0
\end{array}\right.
$$

$s_{i}^{-}, s_{r}^{+}$is the relaxation variable, respectively represent input redundancy and output deficiency; $\varepsilon$ is the Archimedes infinitesimally small, $\varepsilon=10^{-6} ; \theta$ is the valid value of the decision unit which is the relative efficiency of inputs relative to outputs.

\subsection{Entropy analysis}

Wei Shan(2003) established the quality evaluation system of economic growth from the four aspects of stability, coordination, continuity and potential of economic growth, and used entropy evaluation theory to discuss the quality of economic growth in China from 1995 to 2000.[6] Min Wei and Shuhao Li (2018) constructed the measurement system of high-quality economic development level, and used entropy weight method to measure the difference of regional economic quality development level.[7] In the measurement, the lower the information entropy is, the more orderly the system is, and the higher the information entropy is, the greater the uncertainty of its variables is, and the greater the amount of information needs to be examined.

By the J item entropy: $e_{j}=-k \sum_{i=1}^{m} p_{i j} \ln p_{i j}$

Comprehensive economic efficiency coefficient :

$$
v_{i}=\sum_{j=1}^{n} a_{j} p_{i j},
$$

$a_{j}$ is the weight of definition $a_{j}=\frac{1-e_{j}}{\sum_{j=1}^{n} 1-e_{j}}, p_{i j}$ is the index specific gravity.

\subsection{Grey correlation analysis}

Sue-fung Wang, xue-zhen Zhao (2010) argue that education in the economy there are many factors influence each other, showing the characteristics of the "gray" relationship, and by using grey correlation analysis to the relationship between education and economic development level in China for empirical research, confirmed that the strong correlation between education and economic development, education input and output has an obvious role in promoting the economic development of.[8] Grey correlation degree is used in gray mathematics to study the influence of complex factors that interrelate and interact with each other, to determine the factors that affect the essence of things, and to clarify the gray relationship among various influencing factors.

The grey correlation degree formula of parent sequence and sub-sequence is:

$$
r_{i j}{ }^{*}=\frac{1}{n} \sum_{j=1}^{n} r_{i j}(t)
$$

Among then, when $\mathrm{P}=0.5, r_{i j}{ }^{*}>0.6$, achieved best result

\section{RESEARCH DESIGN AND CONSTRUCTION OF INDEX SYSTEM}

Firstly, it starts from the construction of evaluation index of education level and economic growth quality, based on the construction logic, method and standard of literature evaluation index system. Statistical indexes with different dimensions and different aspects of the evaluated indexes are transformed into dimensionless relative evaluation values. This paper firstly uses principal component analysis (PAC) to transform the original index of educational inputoutput level into the main component, so as to ensure the objective reflection of the realistic relationship among the sample indexes. The BCC model with variable return to scale is used to evaluate the efficiency of education level from 2004 to 2019. The DEA projection analysis is carried out to correct the problems of input redundancy and output deficiency in education efficiency level. In the comprehensive evaluation of economic quality, the entropy method is used to reflect the utility of economic growth quality index information. Finally, the correlation between the educational level index and the quality of economic growth in Guangdong Province is discussed through the grey correlation.

Table 1. Evaluation index of educational level.

\begin{tabular}{|c|c|c|c|}
\hline $\begin{array}{c}\text { Level } \\
\text { indicators }\end{array}$ & $\begin{array}{c}\text { Secondary } \\
\text { indicators }\end{array}$ & The index name & Nature \\
\hline $\begin{array}{c}\text { Educational } \\
\text { input index }\end{array}$ & $\begin{array}{c}\text { Human } \\
\text { input }\end{array}$ & NO primary school teachers & positive \\
\cline { 3 - 4 } & NO secondary school teachers & positive \\
\hline
\end{tabular}




\begin{tabular}{|c|c|c|c|}
\hline & & NO High School Teachers & positive \\
\hline & & $\begin{array}{l}\text { NO full-time teachers in } \\
\text { colleges }\end{array}$ & positive \\
\hline & & Primary school number & positive \\
\hline & & Junior high school number & positive \\
\hline & Material & NO high school & positive \\
\hline & & $\begin{array}{l}\text { NO Institutions of Higher } \\
\text { Learning }\end{array}$ & positive \\
\hline & & $\begin{array}{c}\text { To educate the total fixed assets } \\
\text { of the whole society }\end{array}$ & positive \\
\hline & & $\begin{array}{l}\text { The government allocated funds } \\
\text { for education }\end{array}$ & positive \\
\hline & Financial & $\begin{array}{l}\text { Local public finance } \\
\text { expenditure on education }\end{array}$ & positive \\
\hline & investment & $\begin{array}{c}\text { Average public finance } \\
\text { education expenses per student }\end{array}$ & positive \\
\hline & & $\begin{array}{l}\text { Public Finance Education } \\
\text { expenditure budget }\end{array}$ & positive \\
\hline & & $\begin{array}{l}\text { NO aged } 6 \text { and over who have } \\
\text { not attended school }\end{array}$ & negative \\
\hline & $\begin{array}{c}\text { Basic } \\
\text { Education }\end{array}$ & $\begin{array}{c}\text { Illiterate population aged } 15 \text { and } \\
\text { over }\end{array}$ & negative \\
\hline Educational & & $\begin{array}{c}\text { Secondary school population } \\
\text { aged } 6 \text { and above }\end{array}$ & positive \\
\hline indicator & & $\begin{array}{l}\text { NO undergraduate and junior } \\
\text { college graduates }\end{array}$ & positive \\
\hline & Higher & NO postgraduate graduates & positive \\
\hline & & NO patents granted & positive \\
\hline & & NO research projects & positive \\
\hline
\end{tabular}

The data of education level evaluation index and economic increment evaluation index in the study are from 2004-2019 Guangdong Statistical Yearbook, Guangdong Statistical Yearbook of Education Statistics and China Statistical Yearbook.

Table 2. Economic growth quality evaluation table

\begin{tabular}{|c|c|c|}
\hline Level indicators & Secondary indicators & Nature \\
\hline \multirow{5}{*}{ Economic structure } & $\begin{array}{l}\text { Proportion of secondary and tertiary } \\
\text { industries in GDP }\end{array}$ & positive \\
\hline & Urbanization rate & positive \\
\hline & $\begin{array}{l}\text { Year-end balance of deposits and } \\
\text { loans of financial institutions /GDP }\end{array}$ & positive \\
\hline & Investment consumption ratio & positive \\
\hline & Total imports and exports /GDP & positive \\
\hline \multirow{4}{*}{ Economic benefit } & The unemployment rate & negative \\
\hline & Rate of inflation & negative \\
\hline & $\begin{array}{l}\text { Output per unit of energy } \\
\text { consumption }\end{array}$ & positive \\
\hline & $\begin{array}{l}\text { Labor productivity of the whole } \\
\text { society }\end{array}$ & positive \\
\hline \multirow{3}{*}{ Economic potential } & Ratio of RD expenditure to GDP & positive \\
\hline & Technology market turnover & positive \\
\hline & $\begin{array}{l}\text { The proportion of science and } \\
\text { technology appropriations in the } \\
\text { government }\end{array}$ & positive \\
\hline \multirow{3}{*}{ Economic welfare } & Per capita hospital bed & positive \\
\hline & Engel coefficient & positive \\
\hline & Urban green area & positive \\
\hline
\end{tabular}

\begin{tabular}{|c|c|c|}
\hline & $\begin{array}{c}\text { Per capita disposable income of rural } \\
\text { residents }\end{array}$ & positive \\
\cline { 2 - 3 } & $\begin{array}{c}\text { Per capita disposable income of urban } \\
\text { residents }\end{array}$ & positive \\
\hline
\end{tabular}

\section{RESULTS AND DISCUSSION}

Table 3. DEA analysis results

\begin{tabular}{|c|c|c|c|c|}
\hline $\mathbf{Y}$ & $\begin{array}{c}\text { Comprehensive } \\
\text { efficiency }\end{array}$ & $\begin{array}{c}\text { Pure } \\
\text { technical } \\
\text { efficiency }\end{array}$ & $\begin{array}{c}\text { The scale } \\
\text { efficiency }\end{array}$ & $\begin{array}{c}\text { Scale } \\
\text { reward }\end{array}$ \\
\hline 2004 & 1.000 & 1.000 & 1.000 & - \\
\hline 2005 & 1.000 & 1.000 & 1.000 & - \\
\hline 2006 & 0.940 & 1.000 & 0.940 & $\mathrm{drs}$ \\
\hline 2007 & 0.869 & 0.877 & 0.990 & $\mathrm{drs}$ \\
\hline 2008 & 0.859 & 0.869 & 0.989 & $\mathrm{drs}$ \\
\hline 2009 & 0.816 & 0.830 & 0.982 & $\mathrm{drs}$ \\
\hline 2010 & 0.742 & 0.805 & 0.921 & $\mathrm{drs}$ \\
\hline 2011 & 0.780 & 0.813 & 0.960 & $\mathrm{drs}$ \\
\hline 2012 & 0.921 & 0.972 & 0.948 & $\mathrm{irs}$ \\
\hline 2013 & 0.781 & 0.819 & 0.953 & $\mathrm{drs}$ \\
\hline 2014 & 0.751 & 0.800 & 0.939 & $\mathrm{drs}$ \\
\hline 2015 & 0.685 & 1.000 & 0.685 & $\mathrm{drs}$ \\
\hline 2016 & 0.694 & 0.808 & 0.859 & $\mathrm{drs}$ \\
\hline 2017 & 0.764 & 0.851 & 0.897 & $\mathrm{drs}$ \\
\hline 2018 & 0.905 & 0.928 & 0.976 & $\mathrm{drs}$ \\
\hline 2019 & 1.000 & 1.000 & 1.000 & - \\
\hline The mean & 0.844 & 0.898 & 0.940 & \\
\hline
\end{tabular}

In 2004, 2005 and 2019, DEA is effective. The comprehensive efficiency reflects the overall resource allocation of the education level in Guangdong Province from 2004 to 2019, with an average value of 0.844, indicating that the overall education level in Guangdong Province is relatively high from 2004 to 2019. The pure technical efficiency reflects the educational management level and educational system level of Guangdong province, and the mean value of pure technical efficiency is 0.898 . The educational management level and educational system level of Guangdong province are relatively high. Scale efficiency reflects the existing scale of education of Guangdong province and the gap between the optimal scale, scale efficiency mean value is 0.94 , shows the whole higher education scale level of Guangdong province, comparing the scale efficiency and pure technical efficiency, can be found that the overall scale efficiency higher than that of pure technical efficiency, suggests that the education level of Guangdong province is mainly composed of scale efficiency, 。 In addition, education management needs to be further optimized and improved so as to play a positive role in regional economic growth more effectively.

Table 4. Input redundancy and output deficiency analysis

\begin{tabular}{|c|c|c|c|c|c|c|}
\hline & $\begin{array}{c}\text { Comprehen } \\
\text { sive } \\
\text { efficiency }\end{array}$ & $\begin{array}{c}\text { Huma } \\
\text { n input }\end{array}$ & $\begin{array}{c}\text { Material } \\
\text { input }\end{array}$ & $\begin{array}{c}\text { Financial } \\
\text { Investment }\end{array}$ & $\begin{array}{c}\text { Basic } \\
\text { Educat } \\
\text { ion }\end{array}$ & $\begin{array}{c}\text { Higher } \\
\text { Educati } \\
\text { on }\end{array}$ \\
\hline Mean & 0.844 & $15.58 \%$ & $39.39 \%$ & $21.21 \%$ & $0.00 \%$ & $1.07 \%$ \\
\hline
\end{tabular}

From the perspective of input redundancy rate, the average redundancy rates of human input, material input and financial input are $15.58 \%, 39.39 \%$ and $21.21 \%$ respectively, 
indicating that the existing educational input in Guangdong Province has a certain degree of redundancy rate. In terms of the output deficit rate, the output deficit rate of higher education is $0.00 \%$, and that of basic education is $1.07 \%$. On the whole, the educational level of Guangdong Province is mainly affected by the redundant educational input, and it is necessary to further strengthen the effective use of educational input resources

Table 5. Entropy weight method

\begin{tabular}{|c|c|c|c|c|c|}
\hline $\mathbf{Y}$ & $\begin{array}{c}\text { Economic } \\
\text { structure }\end{array}$ & $\begin{array}{c}\text { Economic } \\
\text { benefit }\end{array}$ & $\begin{array}{c}\text { Economic } \\
\text { potential }\end{array}$ & $\begin{array}{c}\text { Economic } \\
\text { welfare }\end{array}$ & $\begin{array}{c}\text { Comprehensive } \\
\text { score of } \\
\text { economic } \\
\text { growth quality }\end{array}$ \\
\hline 2004 & 0.0085 & 0.0022 & 0.0006 & 0.0073 & 0.0186 \\
\hline 2005 & 0.0073 & 0.0049 & 0.0009 & 0.0077 & 0.0208 \\
\hline 2006 & 0.0110 & 0.0059 & 0.0020 & 0.0078 & 0.0267 \\
\hline 2007 & 0.0127 & 0.0064 & 0.0034 & 0.0068 & 0.0293 \\
\hline 2008 & 0.0155 & 0.0052 & 0.0054 & 0.0130 & 0.0391 \\
\hline 2009 & 0.0163 & 0.0122 & 0.0072 & 0.0138 & 0.0495 \\
\hline 2010 & 0.0147 & 0.0093 & 0.0087 & 0.0162 & 0.0489 \\
\hline 2011 & 0.0161 & 0.0087 & 0.0108 & 0.0198 & 0.0554 \\
\hline 2012 & 0.0160 & 0.0115 & 0.0141 & 0.0231 & 0.0646 \\
\hline 2013 & 0.0173 & 0.0138 & 0.0178 & 0.0236 & 0.0724 \\
\hline 2014 & 0.0155 & 0.0149 & 0.0164 & 0.0244 & 0.0712 \\
\hline 2015 & 0.0178 & 0.0148 & 0.0187 & 0.0262 & 0.0774 \\
\hline 2016 & 0.0198 & 0.0149 & 0.0214 & 0.0291 & 0.0853 \\
\hline 2017 & 0.0215 & 0.0169 & 0.0249 & 0.0314 & 0.0946 \\
\hline 2018 & 0.0240 & 0.0189 & 0.0334 & 0.0356 & 0.1118 \\
\hline 2019 & 0.0262 & 0.0202 & 0.0487 & 0.0391 & 0.1342 \\
\hline
\end{tabular}

The comprehensive score of the quality of economic growth has increased from 0.186 in 2004 to 0.1342 in 2019, showing an overall upward trend.

Table 6. Grey correlation between education level and economic growth quality

\begin{tabular}{|c|c|c|c|c|c|}
\hline Y & $\begin{array}{c}\text { Education } \\
- \\
\text { Economic } \\
\text { Structure }\end{array}$ & $\begin{array}{c}\text { Education } \\
- \\
\text { Economic } \\
\text { benefits }\end{array}$ & $\begin{array}{c}\text { Education } \\
- \\
\text { Economic } \\
\text { potential }\end{array}$ & $\begin{array}{c}\text { Education } \\
- \\
\text { Economic } \\
\text { welfare }\end{array}$ & $\begin{array}{c}\text { Education } \\
- \\
\text { Economic } \\
\text { quality }\end{array}$ \\
\hline 2004 & 0.635 & 0.533 & 0.495 & 0.578 & 0.561 \\
\hline 2005 & 0.607 & 0.603 & 0.500 & 0.585 & 0.571 \\
\hline 2006 & 0.729 & 0.660 & 0.537 & 0.610 & 0.625 \\
\hline 2007 & 0.832 & 0.717 & 0.587 & 0.622 & 0.673 \\
\hline 2008 & 0.967 & 0.675 & 0.638 & 0.758 & 0.750 \\
\hline 2009 & 0.992 & 0.928 & 0.711 & 0.810 & 0.882 \\
\hline 2010 & 1.000 & 0.972 & 0.811 & 0.952 & 0.940 \\
\hline 2011 & 0.965 & 0.899 & 0.873 & 0.978 & 0.991 \\
\hline 2012 & 0.932 & 0.960 & 0.914 & 0.983 & 0.974 \\
\hline 2013 & 0.910 & 0.804 & 0.807 & 0.840 & 0.842 \\
\hline 2014 & 0.968 & 0.732 & 0.845 & 0.794 & 0.832 \\
\hline 2015 & 0.810 & 0.701 & 0.715 & 0.709 & 0.733 \\
\hline 2016 & 0.748 & 0.699 & 0.642 & 0.652 & 0.681 \\
\hline 2017 & 0.739 & 0.661 & 0.589 & 0.641 & 0.653 \\
\hline 2018 & 0.746 & 0.656 & 0.482 & 0.627 & 0.614 \\
\hline 2019 & 0.734 & 0.656 & 0.342 & 0.605 & 0.540 \\
\hline Mean & 0.832 & 0.741 & 0.655 & 0.734 & 0.741 \\
\hline
\end{tabular}

The average correlation degree between education level and economic growth quality is $0.741>0.5$. From the four aspects of education level and economic growth quality, the correlation degree of economic structure, economic benefit, economic potential and economic welfare is $0.832,0.741$, 0.655 and 0.734 , respectively. Among them, the correlation degree of economic structure is the highest and that of economic potential is the lowest.

Therefore, the overall results are as follows:
1. The overall education of Guangdong Province has reached a high level in resource allocation, education management and education scale, but there is some redundancy in educational input resources, and the output of higher education is maximized, while the output of basic education is still insufficient to a certain extent.

2. The overall quality of regional economic growth in Guangdong Province presents an upward trend in economic structure, economic benefit, economic potential and economic welfare, among which the economic welfare has the greatest impact on the quality of economic growth

3 . The grey correlation between the education level and the comprehensive index of economic growth quality in Guangdong province is 0.741 , which indicates that the education level in Guangdong province has a great impact on the quality of economic growth.

\section{CONCLUSION}

In recent years, the construction of colleges and universities in Guangdong province has expanded greatly, so Guangdong province should improve the effective use of resources in the construction of colleges and universities.

The pure technical efficiency is lower than the scale efficiency, and the educational level of Guangdong Province is driven by the scale efficiency, so the educational management and system level need to be further improved. Education of Guangdong province level correlation degree is low, the economic potential for higher education to further maintain the existing standard output, technological transformation to the economic and productivity on strengthen the cooperation of colleges and universities, scientific research institutions and private enterprise, integrate the capital resource advantage, promote education on economic potential of the excitation effect, pay attention to the quality of education training to achieve the basis education maximize output.

\section{ACKNOWLEDGMENT}

Funded by Program for Research Development of Beijing Normal University at Zhuhai, and Lixue Project of International Business Faculty, (Project No. 201754021, 201754024, 201850005, 201920001, and 201942).

\section{REFERENCES}

[1] Xue-min Zhang and Xin Chen, Analysis and evaluation of the relationship between education and economic development in China, vol.2. Statistics and Decision Making, pp.123-124, 2010.

[2] Bianhua Li, Setting up the quality index system of economic growth, vol. 1. Statistics and Decision Making, pp. 25-27. 2004. 
[3] Xiaojing Chao, Theory and empirical analysis of economic growth quality in China's transition period, Beijing: People's Publishing House, pp.55-56. 2010.

[4] Shanmai Wang, Reform the educational financial allocation system to improve the efficiency of educational resources allocation, vol.9. Chinese higher education, 1995.

[5] Xue-min Zhang and Xin Chen, Analysis and evaluation of the relationship between education and economic development in China, vol.2. Statistics and Decision Making, pp.123-124, 2010.
[6] Wei Shan, Comprehensive Evaluation of Economic Growth Quality Based on Entropy, vol. 10, The practice and understanding of mathematics, pp. 49-54, 2003.

[7] Min Wei and Shuhao Li, Study on measurement of high-quality development level of Chinese economy in the new era, vol. 11, Quantitative and Technical Economics Research, pp. 3-20, 2018.

[8] Sue-fung Wang, Xue-zhen Zhao, Analysis and evaluation of the relationship between education and economic development in China, vol. 2, Statistics and Decision Making, pp.123-124, 20. 